\title{
State Reconstitution and the Challenge of Democracy in Somalia
}

\author{
Victor Ojakorotu" \\ Department of International Studies, \\ Monash University, Johannesburg \\ L. Andy Afinotan* \\ Department of Political Science and Public Administration \\ Joseph Ayo Babalola University, Ikeji-Arakeji. Nigeria
}

\begin{abstract}
At independence, there were mixed feelings about the potential for survival of the modern state in Africa. This was expected, given the antecedents to the state formation processes that preceded this era. Response of different states to the new demands foisted upon the emergent state structures threw up new challenges which formed the kernel of new internal struggles for power. Colonial practorianism had ensured the centralization of authority at the centre, making competition for control of the centre by emergent nouveau elites a zero-sum game.

In the attempt to restructure the state, many options have been advocated Democracy seems to hold the best fancy, in view of prevailing international norms. Making use of library research and content analysis methodologies, the paper examined the factors connected with the collapse of the state machinery in Somalia and concluded that though the democratic option may be the ideal choice for organizing modern states, it could also facilitate its disintegration. Hence, the paper recommended a blend between the strongman alternative and the democratic option as a viable panacea for restoring legitimacy and authority to the state of Somalia.
\end{abstract}

Keywords : Democracy, state structure, colonial state, practorianism.

\section{INTRODUCTION}

The fact that Somalia could degenerate into serious social dislocation and grievous political disorder may well be a surprise to students of African political studies. This is so because Somalia comes closest to a homogenous nation. Further, Somalia is often referred to as the only nation in Africa within the very strict definition of the term. But in the context of what has happened in Somalia, this has come under serious academic debate. The debate has sometimes focused on whether the Somalian people are a tribe or a nation. In political

\footnotetext{
* The material presented by the author does not necessarily portray the viewpoint of the editors and the management of the Institute of Business \& Technology (BIZTEK) or Monash University, Johannesburg \& Joseph Ayo Babalola University, Ikeji-Arakeji. Nigeria.

${ }^{*}$ V.Ojakorotu :vojakoro@yahoo.com

${ }^{*}$ L. A. Afinotan :andyafinotan@yahoo.com

C JMSS is published by the Institute of Business and Technology (BIZTEK). Main Ibrahim Hydri Road, Korangi Creek, Karachi-75190, Pakistan.
} 
rhetoric the first is currently a term of abuse and the second of approbation (Lewis, 1998). While in other African states, the hydra-headed problem of ethnicity could be deciphered in most national and domestic problems. In Somalia, the society was structured traditionally as clan system. Therefore Clanism has always been a central pillar of the Somali traditional political life.

Thus as Lewis has already stated

"...Clanism is the Somali version of the generic problem of ethnicity or tribalism, social scientists within Somali studies have long focused on an analysis or tribalism..." (Lewis, 1990)

The above equally throws-up salient questions. For instance, Somalia has over the years developed a strong sense of community life exemplified by a common language, a broadly homogeneous and largely pastoral culture and a thorough adherence to the tenets of Islam. Then why this condition of anarchy in which the state has found itself and from which it is still reeling? The social science literature is awash with all kinds of propositions. The central concept or element which has become typical in highlighting the Somalian political system all through this literature is the importance of kinship. Lewis argues that segmented clan system remains the bedrock or foundation, and 'clannishness' which he described as the primacy of clan interest then has the tendency of dividing the society and creating a segmented social structure which in turn is a recipe for "institutionalized instability" (Lewis,1961). In similar vein, Samatar argues that the changes fostered on Somalian traditional lifestyle like the partial commoditization of production and the confusion of kinship with clannishness have both done enough damage to Somalia's existence as a nation (Samatar, 1988.) The transformation of social roles handed to the northern Somalis which sought to alienate them from their traditional role and which was exploited by leading politicians as well as the intelligentsia also played a part. (Samatar, 1989)

The policies of Siad Barre in the northern part of Somalia especially with the Isaaq clan where from 1978-1980 onwards, he instigated widespread violence designed to punish the people of this region have been well documented . As a result of this oppressive rule, the people of this region mobilized into groups. Before long violent revolts had engulfed the north and subsequently spread down. By January 1991, Siad Barre had fled Mogadishu (Battera, 2004).

Events after his departure had assumed such a horrible proportion. Somalia had experienced several peacekeeping operations all supported by international bodies. Notable among these was the United Nation intervention force nicknamed 'Operation Restore Hope' which was mainly an American peacekeeping operation. The ironical angle to these peacekeeping operations is that all have ended in serious failures. Besides this, they have all left Somalia in an even more sorry state than before. It should be understood that Somalia because of its traditional and cultural style is close to what could be described as a decentralized political set up. Its heavy reliance on clan and Clanism which organizes its agro-pastoral life and which provides the line of conflicts along which struggles for recognition have been fought is a testimony to this fact (Battera, 2004). In the same vein, Lewis argues that the Somalis had lived under decentralized clan based politics which is often referred to as 'pastoral democracy'. Deriving from this is the relative peaceful co-existence fostered by decentralized governance. Therefore, it is important to identify two major livewires of social existence which had tended to characterize Somalia. First is a hinterland pastoral and agro-pastoral movement; second is the establishment of many coastal states which developed central administrative and legal systems based strictly on Islamic law (Battera, 2004).

However, it must be noted that after the British Somali-land and Italian Somalia were amalgamated in July 1 1960. The former came to introduce what it called participatory democracy (the latter had completely lost out since the outcome of its ventures in the 
Second World War was not favorable. By this, it had hope that all Somalis would be allowed to exercise their franchise in popular electoral processes. To this end, the British government had introduced multiparty politics. As one could learn from Somali history, this enterprise was indeed the spanner needed to undo the nut of unity that had been the hallmark of the lives of the Somali people. Intrigue, dangerous cross carpeting, high level of corruption within the rank and file of politicians, the serious tribalism built into party politics all combined to give a warning signal. An attempt to change the government actually took place but failed until 1966 when army officer Siyaad Barre led a successful coup that overthrew Somalia's postcolonial parliamentary democracy and established the Siyaad led Supreme Revolutionary Council as the ruling body (Besteman, 1996). The policies of Siyaad Barre, as earlier noted gave rise to a systematic breakdown of order ultimately leading to anarchy.

It is against this background that this paper seeks to examine in an analytical perspective the real issues involved in the Somalian imbroglio, with a view to addressing the following fundamental posers: What are the basic contradictions within the Somalian body-politic that seem to make conflict and internecine violence inevitable in a mono-ethnic post colonial state? Why has democracy and its socio-political imperatives which has been so successful as a worldwide political credo seem to fail so pathetically in Somalia? What are the real challenges to reconciliation, state reconstitution and democratic consolidation in Somalia? What are the probable options available to the people in the current circumstances? It must however be stated here that whereas this paper does not in any way, lay claim to the capacity to provide all the answers, it would nevertheless constitute a modest contribution to the available literature dedicated to finding dependable solutions to the Somalian question.

\section{CONCEPTUAL FRAMEWORK FOR ANALYSIS}

Against the background of the fact of a complete breakdown of law and order in Somalia, and the subsequent descent into anarchy in a social Darwinist perspective, our preferred conceptual framework for analysis of this problematic is the theory of international social Darwinism. This paradigm depicts nations of the international system as being in a constant state of evolution and development through competition and anarchy in a Hobbessian perspective, resulting in the survival of the fittest and the elimination of the weak.

In the arena of combat between whole peoples in which the destiny of humanity is determined, the role of war is to pass the reins of power from the weak and decaying to the strong and dynamic (Rosen \& Jones, 1980). This philosophy has come to be associated with fascism, a doctrine which does not believe either in the possibility or in the utility of universal peace, equating pacificism with cowardice. Advancing war as a positive aspect of fascism, Bernito Musolini asserted that;

"...war alone brings all human energies to their highest tension and sets a seal of ability on the peoples who have the virtue to face it..." (Musolini in Christensen et al, Quoted in ibid)

Nazism, a state philosophy under Adolf Hitler and a virulent and advanced form of fascism also believes in the social Darwinist approach to Politics. According to Adolf Hitler in his famous work Mein Kampf;

"... Nature knows no political boundaries. First she puts living creatures on this globe and watches the free play of forces. She then confers the master's right on her favorite child, the strongest..." (Hitler, 1943; 134-157;Quoted in op.cit)

In the thinking of the social Darwinists it amounts to an abdication of duty bordering on irresponsibility, not to fight wars of territorial expansion and acquisition, since this lapse will immediately result in a scenario where mastery of the world will be left to the weak 
and culturally inferior. The philosophy of social Darwinism thus glorifies conflict and extols the virtues of war, giving as it does a raison d'etre for imperialism and war mongering between states and among peoples. This philosophy was a major cause of war in the international system and particularly the Second World War. Although fascist and Nazi movements are now nearly dead, the philosophy of international social Darwinism is not only alive and well (op.cit), it is once again actually playing itself out - this time in Somalia.

This paradigm is of course very apposite to the Somalian situation where the unending and bloody battles between the Clans is a struggle for control of state power by rival Clans or group of Clans, determined to wrest control of state apparatus through military superiority, in the process of state reconstruction and nation building. The rise of Warlordism and the use of religion and ideology by rival clans to secure the help of foreign allies most eloquently testify to this fact. What is even more indicative of this is the apparent unwillingness of the rival gladiators to accept an international peacekeeping mission to broker a democratic alternative even after several years of violence and bloodletting. Viewed from this perspective the social Darwinist instinct behind this struggle is unmistakably displayed in bold relief.

\section{THE SOMALIAN PEOPLE AND TRADITIONAL DIVISIONS}

Somalia represents what could rightly be called a nation, and is, as a socio-political entity quite unique by comparison to other African states in terms of structure and composition. It is however pertinent to consider how this concept of a nation with its imperatives of historical and cultural homogeneity presented itself in Somalia against the background of the development in other part of Africa in the immediate post independence era .There is no doubt that many African states experienced near-collapse during this period owing to factors that could be linked to tribalism. This phenomenon (tribalism)was however not expected to be a feature of political life in Somalia, in view of the socio-cultural homogeneity of that country. But Somali politicians of the post independence era attested to the fact that the major divisive force behind the collapse of the Somalia's first republic was actually tribalism. Tribalism worked quite differently in Somalia by comparison to the situation in most African states, but the effect on national politics remained the same. Explaining this peculiar situation, Lewis (1972) posits;

... It is thus clanship in the technical sense rather than tribalism, which command allegiance and frustrates the achievement of much that is in the national interest...

The Somalis are somewhat related to the Afar in Djibouti, Eritrea and Ethiopia to the Oromos, Shako and Beja in Ethiopia (Adams, 1972; 12). They equally share the same language (close to the Cushitic group), a common religion (Islam) a common culture (Xeer, or political contract). Identification with the Somali language is often seen as highly important Poetry recitation, Somali song and proverbs are in fact "treasured" and one's ability to speak the language very well is a "necessary condition for political authority". It should also be noted that Somalis share an unquenchable multi irredentist disposition which could only be explained by inherent die-hard nationalism. And to this extent it has always sought to integrate Somali stock around the 'parent land' together. The five pointed star on the Somali flag represents the northern and southern regions of the present Somalia, the yet to be liberated North -eastern part of Kenya, the Ogaden province of Ethiopia and the French territory of Afar and Issas.

Furthermore there are six most significant clan groups in Somalia. These are; Dir in the north-west extending as it were into French Somali land, the Isaq are at the center of the northern region. The Darod are wedged between the former British protectorate and Northeastern Somalia and again having another leg in eastern Ethiopia and northern Kenya. This particular clan is the most distributed and the largest among the six groups. This explains why they are always at the fore front of the irredentist claim. Again its also explains why Doctor Abdirashid Ali Shirmarke and Siyaad Barre both Darod tended towards the unification of all Somalia in the Diaspora. The same could not be said for a leader like 
Adan Abdulle Osman a politician of Hawiye clan who became the president of the republic at independence. A third clan the Hawiye, occupies areas around Mogadishu and its environ and equally extends into Kenya. Typical to all, the four mentioned above is the fact that they are all traditional pastoral nomads. The remaining two clan groups are the Digil and Rahaweyn .This group occupied the so called fertile space between the Juba and the Shabelle rivers. Their occupation is largely farming and the large banana plantations could be found here. Together, the Digil and the Rahaweyn speak a distinctively different brand of Somali and for this reason they are often discriminated against. Lewis (1972), even argues that these two clans (constitute in fact the only division with sufficiently developed cultural differences to warrant the term tribalism) (Lewis, 1972). The six forms the main genealogical tree but of course they become too large for any political governance, instead they are broken up into clan, sub clan and even sub sub-clan for effective administration and easy mobilization.

In separate instances, scholars like Adams and Lewin attest to the sacrosanct height to which struggle for equality and recognition in Somalian society has attained. This struggle could be seen among individuals, sub clan and sub sub-clan. The struggle could even be more intense among the educated Somalis who have pastoral background and who one way or the other could speak one or two of the colonial languages. The struggle, therefore continues in its original form because no group is able to dominate the others. In essence, Adams emphasizes the importance of "material basis" as having direct linkages with the struggle for recognition. For Lewin, for all of Somalia's "republicanism and individualism", as a direct result of a highly decentralized entity, "the figure of a tyrant and despot seems always to have held a curious fascination for the pastoral nomads."

With this kind of a near lawless society, a modicum of civility is usually established through a traditional political set up known as Diya or blood compensation for wrongs committed by any group member. This system has indeed governed Somali in pre-colonial times and prevented it from plunging into the disaster we are witnessing in the Somalia of today. Similarly Ahmed Samatara explains kinship in the Somalian social order thus:

\begin{abstract}
"...The ideology of kinship had two central elements: blood ties and Xeer the first was essentially a product of genealogical connections buttressed by a Patrilineal system harking bark to a real or invented common origin /ancestor: The latter was an embodiment of common wisdom and the locus of inter/intra generational and, in its most general depiction, a pan-Somali code of conduct. The combined meaning of this element constituted the milieu in which both the private and the public were defined. This, then, was the basis of kinship - an ideology commensurate with reciprocal production relations..." (Samatara, 1993)
\end{abstract}

According to Samatara, pre-colonial Somalia was administered by a set of rules and norms known as Xeer. With this Xeer, Somali resembled something of a governable society as distinct from what the social and clan composition denote. In case of clashes among rival clans its members come together to fight and claim compensation on his behalf. In such cases, the particular diya -paying group responsible for such is not only held accountable, but also kin and allies of the particular group. The moment fighting ceased between rival groups, and compensation meted out and paid, the situation returns to normal and the status quo is thereafter maintained. Given the above scenario, it becomes almost impossible for one household, lineage group or clan to dominate the others.

\title{
4. STATE RECONSTRUCTION
}

State reconstruction involves an attempt to integrate, socialize and unite people under the umbrella of a single national government, in a single socio-political expression within the boundaries of a given territory known as the state. State reconstruction is often a desperate necessity in those socio-political milieux where colonialism has imposed upon local populations arbitrary political and administrative boundaries, compelling culturally diffracted populations to come together under the umbrella of a single state. State reconstruction in 
such circumstances also has to focus on identifying with a 'oneness' of purpose among the people. But to what extent can one say this concept is workable in Africa? It should be realized that very many African states boast of a mosaic of cultures and peoples. In essence therefore, ethnic divisions are so prevalent that the act of state reconstruction could be said to be hardly possible in many post-colonial states of Africa. Recently there has been a new and vigorous push towards states reconstruction by major international organizations. The UNDP had been very visible in this regard, such that it had dedicated several reports to building a new model for addressing the problem of state crisis.(Battera, 2004)

Despite this novel attempt at conceptualizing and implementing state reconstruction, the necessary pre-requisites are usually absent in many societies. Most societies reeling from the effects of war are usually also experiencing deep-seated cleavages among their citizenry usually drawn along their ethnic seams. It is therefore possible for such people to see themselves as ethnic categories. In such situations, the business of state reconstruction becomes a rather tedious one.

\section{SOMALIA RECONSTRUCTION}

That Somalia existed largely as a very loose and highly decentralized entity in pre-colonial times has enjoyed a respectable place in the literature (Lewis, 1994). After the merger of the two republics, they operated through a constitution merger. Though there were some grey areas. The two national legislatures equally emerged to form a single parliament with 123 seats: 33 for north, and 90 for the south (Lewis, 1972). A power-sharing formulation was evolved such that leading political positions were carefully spread out among the six major clans. Adan Abdulle Oan, a Hawige was elected as the president of the republic, Dr Abdirashid Ali Shirmarke, a Darod, was appointed prime Minister.

The politics of the period from 1960 to 1969 were characterized by alignment and undue comradeship. Politicians sought positions and parties with which to further their personal and political interests. Therefore it was not out of place for mass cross-carpeting of parties to happen in parliament. Politicians were getting insulated from their people and constituencies by the day, while corruption was on the rise. Politicians who had spent a fortune during the electoral campaign were on the look out for reimbursement at the slightest opportunity. As the years passed, national oriented political parties degenerated into clan, sub clan and even one man parties such that by the end of the decade, Somalia was suffering under a general atmosphere of cutthroat competition, corruption, incompetence and irresponsibility. (Adam, 1992)

On assumption of power by the Siyaad Barre-led Supreme Revolutionary Council, it set out to outlay certain stereotype in the life of Somalia. Terms such as 'Clan' 'tribalism' or any kind of reference to 'ethnic affiliation' could cause the wrath of government. Lewis told of how:

“...Effigies representing "tribalism, corruption, nepotism and misrule" were symbolically burnt or buried in the republic's main centers... The word comrade(jalle: friend, chum) was launched into general currency with official blessing to replace the traditional polite terms of address, "cousin"(ina'adeer) which was now considered undesirable because of its tribalistic kinship connotations..." (Lewis, 1988)

After this, Barre embarked on literacy campaign which was designed to institutionalize a national lingua franca. The communist socialist ethos had serious appeal to the new government. Therefore socialist -inspired control of discourse sought to reverse the causal relationship between language and 'doxa' (Besteman, 1996). Before the coming of the Siyaad administration, English and Italian were freely spoken especially in parliamentary proceedings and were deemed as the official language of the Somalis. However, the Somali society was such that very few could speak these languages because the percentage of educated Somalis was very small. In what looked like a change in policy, the Barre 
administration sought and infact promoted "standard" Somali as the official language. Siyaad belief on this subject was captured thus:

“...The key is to give everybody the opportunity to learn reading and writing... it is imperative that we give our people modern revolutionary education...to restructure their social existence... it will be the weapon to eradicate social balkanization and fragmentation into tribes and sects. It will bring about an absolute unity and there will be no room for any negative foreign cultural influences..." (Lewis, 1988)

Again in a further attempt at bizarre nationalism, Siyaad closed down schools between 1974-75 and sent all teachers and older students into the hinterland to educate the less privileged about the new found concept regarding 'education for all'. Not only this, nomads and pastoralists alike were to be taught writing skills. The success of this country-wide educational campaign left much to be desired. This is because Somalia with its characteristics as a divided society has inbuilt constraints which are detrimental to such novel intentions. Siyaad Barre's greatest nationalist fervor was shown over his desire to bring together the people of Somalia home and abroad. The Somali Diaspora included chunks of population scattered in neighboring countries such as Kenya, Tanzania, Ethiopia and part of Uganda. Ethiopia naturally harbors the largest population because of the proximity of the northern fringes of Somalia and Southern Ethiopia. As a result of the balkanization and the tradeoff which resulted after the World War II has been lost and won, ethnic Somalis were cut off from their original kit and kin retaining a large portion in Somalia.

Immediately after Siyaad's ascension into presidency, he sought to unite this Somali element in what was to assume a directly confrontational foreign policy pursuit. The reason behind this position is not very clear. Before Siyaad, the previous government of Mohammad Haji Ibrahim Egal believed in a policy of rapprochement as one in the best interests of Somalia and in this regard, his government dedicated enough time to pursuing policies in this line. Ethiopia and Kenya enjoyed cordial relations with Somalia during this period. Barre sought an immediate reversal to this issue of irredentism. Probably, he thought that the majority of Somalis craved for this unity or maybe it was actually Barre's war. It is very hard placing his mindset.

By the 1980s, Somalia nationalism not only waned but has begun to show some strain. Siyaad had lost the war over the Ogaden and his focus had now shifted homeward albeit repressively. State rhetoric claiming national homogeneity were belied by the continuing salience of regional linguistic pattern, cultural heroes, and economic concerns, the growing significance of class, competing economic interest...'(Besteman, 1996). In fact the loss of the war was seen by many to be the beginning of the Siyaad's political decline (Cassanelli, 1993). Siyaad began a dangerous pursuit of setting clan against each other such that tension was brewed among clans of the same kinship. This reached devastating effect by the early 1990s. According to Christopher Clapham,

“...As the resources available to the central government declined, and its authority weakened, previously 'loyal' clans gained an incentive to cross over to the opposition, and the whole exercise had to be repeated, but from a weaker starting point than before..." (Clapham, 2002)

Even major clans such as the Digil and Rahanweyn had their share of the repression and in-fact were the most oppressed of the six clans. The transformation which has been fostered as a result of militarism and militarization had affected their core social and cultural life. The Digil and the Rahanweyn are principally agro pastoral and because of their disinterest in participation in Somalia politics, the struggle for arms and ammunitions was very alien to them. To the population of the north, Siyaad did not fare any better,

"...Siyaad's politics in the north had begun to breed revolt among the Isaaq, the largest northern clan-family, who felt excluded from politics and the state resources..." ( Lewis, 1994) 
The administration also exercised efforts to wrest control of livestock exports and sales of qat from Isaaq merchants and entrepreneurs and 'his settlement of Ogadeni refugees in Isaaq-dominated territory were generally seen as part of a continuing subversion of northern interests by a southern-dominated government (Schraeder; 1993). All these were done with the sole aim of "undermining the economic and political strength of the Isaaq clanfamily" (Cassanelli, 1993). Siyaad bared his fangs when in 1988; he embarked on a punitive bombing spree of the northern cities and villages such that large numbers of northerners had to escape and ended up as refugees in Ethiopia. Similarly, corruption was at a high level. This was as a result of large foreign aids coming through western donors, multilateral organizations and friendly Arab states like Egypt and Saudi Arabia. The strategic importance of Somalia had come to the fore in this period as it came to be viewed in good light by both the United States and the old USSR. It was supposed to be stabilizing force in the Horn of Africa as the struggle for the 'mind of men' reached a crescendo in the cold war period.

With the negative policies highlighted above the government became isolated and insulated from the citizenry. The death knell for Somalia came as the Cold War ended, military apparatus mainly recruited along clan lines started to rely on the territory to endure, setting up a situation of total anarchy and a situation whereby each clan had to secure its subsistence. Warlordism became the order of the day.

\section{WARLORDISM}

The term warlordism is a direct consequence of a decline in central governance (Roberts, 1989). As law and order breakdown, individuals started organizing along ethnic and clan lines to secure their safety. In Somalia, the militarism and militarization contributed largely to this situation. As was noted by Samatar (1988)

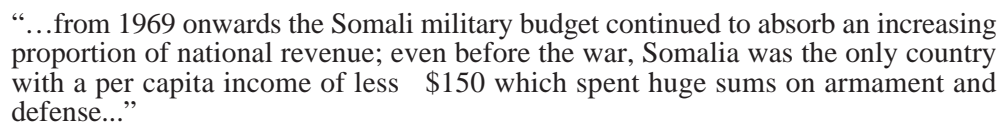

"...from 1969 onwards the Somali military budget continued to absorb an increasing proportion of national revenue; even before the war, Somalia was the only country with a per capita income of less $\$ 150$ which spent huge sums on armament and defense..."

It has been argued in the literature that warlordism is not only related to breakdown of order. A critical look at these literatures would equally suggest a situation of lawlessness. For instance, it was suggested that warlordism is not a new phenomenon in Somali politics, as it occurred during the 'civil war' which ravaged Somalia during the period of colonial expansion (Battera, 2004). With the collapse of the Siyaad administration, warlords took over the reins of government, setting up their own territory and recruiting willing elements. Surprisingly, warlords became very important in the chaotic Somalia situation, maintaining serious linkage with external forces through illegal means. As would be seen later, the United States led coalition of 'Restore Hope' was always at the mercy of the warlords. Extreme cases of extortion from aid agencies by warlords were reported. At some other instances 'protection' and 'security' by guards from by warlords are not only charged in dollar equivalent but very heavily. Coalition contingents, precisely the Italians, were reported to have bribed the warlords not to attack them (Clapham, 2002). When the United Nations forces eventually pulled out in 1995, they were alleged to have bought their way out of Somalia at a cost of about $\$ 30$ million (The Times, London, 28, Feb; 1995).

\section{STATE RECONSTRUCTION AND DEMOCRACY IN SOMALILAND}

For so many decades, Somalia had no meaningful contact from outside the country that could strongly put it in a path of recovery and state building. This goes a long way in telling a story of deep-seated anarchy and destruction of any existing social fabric while many regions were under the heavy rule of warlords. The northern region which had come to be known as Somaliland was a classical example of state reconstruction and state- 
building. The Burco conference of 1991 helped to concretize agreement on reconciliatory initiatives regarding Somaliland state building processes. Furthermore, other conferencesBooroma 1993 and Hargeisa 1996 followed, with the intention of creating an acceptable constitution and some other institutions. It was the former conference which produced the National Charter specifying the adoption of a political system, the formation of a new federal structure and the creation of an acceptable power-sharing formula. It was recognized that it is very important to fuse indigenous forms of social and political organization with western form (Progression Report 2005).

The presidential form of government and a bicameral legislature was equally adopted. The legislature is made up of an upper house of elders (Golaha Guurtida) and the lower House of Representatives (Golaha Wakiilada). The Hargeisa conference of 1996 was a direct response to the shortcomings of the earlier Booroma conference. Here the term of office of the president was fixed to five years. Secondly, the National Charter was replaced with a draft constitution. This was achieved after a serious disagreement between the government of Ibrahim Egal and the two houses of legislature. The constitution also provided for necessary transformation from a clan-based consociational government to a multiparty system. For the first time, universal adult suffrage was given to women. Furthermore the constitution allows for limited multiparty politics. This is because of the experience of the Somalia first republic where party affiliation became regional and clan-based.

Despite the adoption of democratic and multiparty ethos, Somaliland was not accorded recognition by the international community as was the thinking of its top leadership hierarchy. During the election, six political parties fielded candidates, "of which three won sufficient support to become accredited national parties"(ibid). The successful parties were those of Ibrahim Egal's United Democratic peoples Party (UDUB), Kulmiye (unity Party) and the UCID (Justice and Welfare Party). The UDUB won the presidential election with its candidate Dahir Riyale Kahin pronounced president.

With the successful completion of the elections, Somaliland has come to demonstrate it could manage its affairs without much external interference. The election was funded from within, with little support coming from abroad. Again the election highlighted the possibility of conflict resolution in a divided society like Somali and Somaliland. Though elections result and voting pattern show affiliations along regional and clan lines, there is a marked difference from what was obtainable in the larger Somalia republic before Siyaad coup. Titled elders, the presidency and prominent paramount chiefs play a great role in issues of reconciliation and settlement of disputes especially those touching on issues of national scale. An example of this was seen when the president, Ibrahim Egal mediated and consulted widely before deciding the fate of Sanaag and Sool provinces. The two regions had been subject of intense struggle between punt land and Somaliland. Commitment to reconciliation and what has been seen as the novel attitude of the Somali National Movement forces that had learnt to be subservient to civil rule, as against military might were deciding factors in the relative success recorded by Somaliland.

As earlier noted above, the Somali decadence and subsequent erosion of legitimacy coupled with widespread corruption ultimately lead to a total collapse of governance at all levels. Consequently state building or reconstruction has to begin in earnest. One of the major challenges is how to locate issues of common interest in which consensus would be reached. Battera captures this succinctly when he argues that the Booroma Charter and the Hargeisa peace process shared out different roles to recognized law making bodies.(Battera, 2004)

The internal resilience and the will to end the crisis are the most important factors necessary in locating a true path to reconciliation. Though external forces might be crucial, it is the will shown by the locals themselves that would prove essential.

Somaliland, just like Somalia stood the chance of relapsing into serious conflagration, but chose the path of peaceful co-existence and election, and "discovered a formula for a 
successful state -building process by combining imported institutions with informal notions of governance rooted in Somali culture"(Battera, 2004).

\section{STATE RECONSTRUCTION IN SOMALIA - ALTERNATIVE FUTURES}

From the fore-going analysis, one thing becomes obvious; there is currently no truly national government in Somalia. Although it is true that much of what constitutes Somaliland and several parts of northern Somalia are relatively peaceful, inter-clan and inter factional fighting can flare up with little warning. Kidnapping, murder and other threats to foreigners can occur unpredictably in many regions of the country. The incidence of piracy in the territorial waters and high seas of the coasts of Somalia, under the auspices of sectional warlords and sundry militia groups, is in spite of concerted international efforts yet to be completely stamped out.

It is pertinent at this stage to recall that, following the demise of Siad Barre's central regime in 1991, the resultant socio-political dislocation, chaos and an imminent humanitarianism disaster had forced the international community under the auspices of the United Nations to intervene militarily in Somalia by 1992. The United States-led peace keeping operation had succeeded in creating an enabling environment for the deliverance of substantial assistance to the Somali people. By March 1993, the potential for mass starvation in Somalia had been effectively stemmed. In spite of this, the security situation had remained volatile, with US troops receiving significant casualties in battle with Somali militia. Nineteen US soldiers had been killed and over 80 wounded in various confrontations by October 3, 1993 forcing the US to withdraw its troops in 1994.

When the United Nations finally withdrew from Somalia in 1995 neither peace nor order had been restored. In spite of this, the UN had continued to assist Somalia with food aid, and by the close of the decade (1990s), relative calm had begun to emerge and economic development somewhat accelerated. Conflict between rival warlords had however continued throughout the 1990s, and the country was by no means stable. By the year 2000 a transition government had emerged but was unable to hold on to power for any significant length of time.

In the same period, two regions of the North, Somaliland and Puntland broke away from the country, but none of them found any recognition from the international community. But after the September 11 terrorist attack in the US, that country started to take a more active interest in Somalia's affairs, fearing that the country could become a haven for terrorists. This was also a catalyst for other Western governments which for the same reasons wanted peace in Somalia .

In January 2004, about twenty four local warlords reached a power sharing agreement after peace talks in Kenya. This agreement called for a 275 -member Parliament under a transitional federal arrangement for the country. This transitional federal government (TFG) was the 14th attempt at forming a government since the departure of Siad Barre in 1991. Although its leader Abdullah Yusuf, originally called for African peacekeepers to help restore order in Somalia, but this could not be implemented as many Somali's feared invasion by Ethiopia.

In May 2006, heavy fighting broke out in Mogadishu between the TFG Warlords and the Supreme Islamic Courts Union, (ICU), which was formed in 2000 by former members of al-ittihad-islamiya (AIAI).This group has fought along with the ethnically-Somali Oromo liberation front (OLF). Both forces sought the secession of the Ogaden region from Southern Somalia. The TFG and a group known as the alliance for the restoration of peace and counter- terrorism were believed to have been funded from America. But in June 2006 the 
ICU seized control of Mogadishu and much of southern Somalia, forcing Yusuf's TFG to retreat from Jowar to Baidoia. Although the TFG still hoped to wrest control of much of the country from the ICU with the backing of Ethiopia, it had as at July 2006 done very little to actualize this.

The ICU on the other hand had begun the process of setting up a conservative Islamic state over the territory under its control. In spite of another peace meeting between the TFG and the ICU in Khartoum in June 2006 peace could not be brokered by October 2006. TFG and ARPCT forces began to mount attacks on ICU locations in the strategic town of Burahakaba, located $50 \mathrm{Kms}$ south of Baidoia on the road to Mogadishu. By November 23 2006, Prime Minister Meles Zenawi of Ethiopia had declared an Islamic war against the ICU and five days later, Ethiopian troops engaged the ICU at Bandiradley, a strategic town north of Mogadishu.

On the 7th of December 2006, the UN Security Council voted to authorize an 8000-man strong peace-keeping mission, built from the forces of the members of the inter-governmental authority on development (IGAD). The seven members of IGAD are; Djibouti (former French Somaliland), Eritrea, Ethiopia, Kenya Somalia, Sudan and Uganda. These members support both sides to the conflict, but the UN resolution also eased a 1992 arms embargo against the Somali government.

It is pertinent to recall here also that in November 11 2006, the ICU did announce that it had reached a peace deal with the TFG which was apparently represented by Sheikh Adan. But the immediate repudiation of the deal by government on the grounds that Sheikh Adan did not have its consent to negotiate on behalf of the government, scuttled that claim. But bolstered by the December 7 UN resolutions, and aided by Ethiopia, the ITF attacked ICU positions on 8th December 2006. An ICU counter attack meant to cut -off Baidoia from Ethiopian assistance targeted a town near the Somali-Ethiopian border. It is estimated that over one million Somalis have died from the conflict since 1991.

At this point the search for peace in Somalia has become synonymous with the search for a consensus-based central government capable of commanding the respect and obedience of all citizens of Somalia. It is fairly obvious that no warlord or group of warlords will become able to achieve this by force of arms on a sustainable basis. Whichever group seems to have an upper hand in the battlefield today could only hold on to power temporarily, until yet another group is able to mobilize sufficient support to effectively challenge their authority once more. Thus an unending cycle of conflict and chaos seems to loom in the horizon without there being any prospect for peace and stability on a sustainable basis.

The question to be addressed however remains what system of government can best provide a sustainable framework for socio-political rapprochement between the warring clans? It is obvious that warlordism by its nature presupposes the existence of personal or group agenda. Whereas the Somalian question remains basically an issue of conflict of subnational interests and agenda, the one is juxtaposed upon and has become closely, if not inseparably intertwined with the other. Democracy and popular elections is a widely held socio-political credo the world over. For now there is really no viable alternative to this, in this age and epoch in the development of the human race. Somalia as a post-colonial and an aspiring modern nation-state cannot be an exception. But democracy cannot take root and flourish in an atmosphere of chaos and endemic instability.

Somalia must therefore find relative peace through negotiation and consensus, in order to provide a reprieve for the nation to conduct preliminary elections to put in place a transitional government of national unity. This will necessarily involve serious and wellmeaning attempts to reconcile sectional, group and personal interests across the country, without trying to apportion blames for all that has happened since independence. After eighteen years of fighting, there is probably beginning to set in, a certain degree of war weariness which should act as incentive to peaceful resolution. The fact that over fifteen 
attempts at negotiated peaceful settlement has taken place since 1991 testifies most lucidly to this point.

Besides, with the close monitoring and policing of the territorial waters and high seas by international naval formations, piracy and kidnapping for huge ransoms is becoming much less attractive to warlords in search of funds to prosecute their campaigns. In addition, the victory in the US presidential elections by Barrack Obama seems to have been received with joy and optimism not only by the government in Somalia, but also by the various contending groups in the debacle. America under the leadership of a black President of African, and especially of Kenyan origin is in a very good position to find widespread acceptability, and consequently also a listening ear from the factional warlords and the government in Somalia. America today is in a unique and strong position to mobilize international opinion and support for the peaceful resolution of the conflict, and to help in the process of state reconstruction and nation-building in Somalia. Perhaps the international situation at this time and the domestic conditions in Somalia favor resolution through consensus and peaceful settlement of the Somalian conflict.

However, it must be remembered that this will not be Somalia's first attempt at democratic government. The major contradictions that conspired to defeat Somalia's fledgling democracy in the years between 1960 and 1969 are even more pronounced now. The problems associated with ethno-elitism and a politics of prebendalism in zero-sum perspectives, upon which framework the evils of corruption, maladministration and incompetence was juxtaposed, is even now more pronounced. All of these have been honed through internecine conflict and fierce tribal loyalties.

In this perspective, democracy with its attendant imperatives of rule of law and freedom of decision seemed to have been the most important facilitator of Somalia's disintegration as a nation-state. Somalia was evidently not adequately prepared for it. Consequently, even where democracy must be acknowledged as the best choice for organizing modern states, it is by no means a sufficient condition for peace and stability, as has been so eloquently demonstrated by the Somali experience. Therefore, the on-going as well as future attempts to address the Somalian question through the consensus and peace option, must consider other alternatives and perspectives for the building up of sustainable government, genuine national reconciliation and state reconstruction in the region.

\section{RECOMMENDATIONS AND CONCLUSION}

Against the background of the above analyses, a number of features must become observable. First is the fact that there is no viable alternative to democracy as a system of government for organizing modern societies. Second is that the experience in Somalia has proved that although democracy may be necessary, it is yet not a sufficient condition for peace and stability. It may even be a recipe for chaos in emergent post-colonial societies. Therefore in its essence democracy must be seen as a process which grows and matures with experience, and thus become beneficial and therapeutic to chaos and disorder, only when it has reached a certain stage of maturity. The Somalian experience is a pointer to this fact.

Third is the need to address the issues related to the politics of warlordism in Somalia. It is fairly obvious that, in this peculiar circumstance, no one wishing to address the Somalian situation can afford to ignore this fact. The warlords have personal and group interests to protect, and this must be acknowledged and addressed within the framework of a democratic system. A power-sharing arrangement under a federal constitution, which leaves executive powers in the hands of the feuding warlords, is recommended. Within each of the component units, further power sharing arrangements that could cater for the subsidiary groups within each unit permitting each important war-time commander to benefit to a commensurate degree is also encouraged. 
At the national level, an elected leader is recommended who was also a warlord, capable of reconciling competing interests while becoming at the same time, (and when the need arises) capable of the strong arm alternative. This is to enable him have a firm grip of the federation and become capable of taming adventurous unit leaders. The democratic constitution must grant emergency powers to the federal government to make this possible, at least for the first twenty years of a new democratic dispensation.

Finally, the tendency towards irredentism must be suspended for peace to return to Somalia. Rapprochement with the states of Ethiopia, Eritrea, Kenya and Djibouti is also an unavoidable sine-qua-non. This must form a major item in the reconciliation agenda. Amnesty must also to be granted to all war-time leaders to facilitate a re-integration into the national union.

\section{REFERENCES}

Battera, F. (2004) State and Democracy- Building in Sub-Saharan Africa: the case of Somaliland- A comparative perspectives; Global Jurist Frontiers 4(1)

Besteman, C.(1996)Violent Politics and the Politics of Violence: The dissolution of the Somali Nation-State

Cassanelli, L.(1993) "Explaining the ethnic conflict in Somalia." Paper presented to the workshop on High conflict /Low conflict: Six case studies of ethnic conflict. Woodrow Wilson internationalcentre for scholars, Washington D C.

Clapham, C. (2002) Africa and the International system. Cambridge: University of Cambridge Press.

Hussein A (1992), Somalia: Militarism, Warlordism or Democracy?; Review of African Political Economy

Lewis , I. M (1961) A Pastoral Democracy. Oxford: Oxford University Press.

Lewis, I.M. (1988) A Modern History of Somalia: Nation and State in the Horn of Africa. Boulder, Colorado: Westview Press.

Lewis (1994) Blood and Bone: The call of kinship in Somalia. Lawrenceville, New Jersey: Red Sea Press

Microsoft Encarta (2008) "The Somalia Civil War."

Roberts, J.A.G (1989) WARLORDISM IN China, Review of African Political Economy, $45 / 46$

Rosen S.J. and Jones W.S.(1980) The Logic of International Relations. Cambridge, Massachussets: Winthrop Publishers.

Progression Report 2005, Further Steps to democracy: The Somaliland Parliamentary elections

Schraeder, P. (1993) US Intervention in the horn of Africa amidst the End of Cold war. Africa Today, 40(2). London: Africa Books Limited.

Samatar, A. (1988) Socialist Somalia: Rhetoric and Reality. London: Zed Books.

Samatar, A.(1989) The state and Rural transformation in Somalia, 1884-1986. Madison, Wisconsin: University of Wisconsin Press.

The Times. London, 28 Feb; 1995. 